\title{
You Gotta Let Love Move
}

\author{
ECJ 5 June 2018, Case C-673/16, Coman, Hamilton, \\ Accept $\mathrm{v}$ Inspectoratul General pentru Imigrări.
}

Jorrit J. Rijpma*

\section{INTRODUCTION}

With its ruling in the Coman case, the European Court of Justice has provided much overdue legal certainty for married couples of the same sex regarding their rights of free movement under EU law. ${ }^{1}$ The Court, sitting in Grand Chamber and following Advocate General Wathelet's opinion, made it clear that a member state is obliged under EU free-movement rules to recognise a marriage, legally concluded in another member state, of an EU citizen to a partner of the same sex. ${ }^{2}$

*Associate Professor of European Law and Jean Monnet Professor, Europa Institute, Leiden Law School. Some of the ideas underlying this case note were previously expressed in J.J. Rijpma, 'Annotatie', 137 JV 10 (2018) and J.J. Rijpma, 'A Spouse is a Spouse', Regulating for Globalisation, 8 June 2018, (www.regulatingforglobalization.com/2018/06/08/a-spouse-is-aspouse/ $\rangle$, visited 29 April 2019. The author would like to thank the European Law Section of the Dutch Ministry of Foreign Affairs for swiftly handling his request for access to the written submission of the intervening governments and the Commission. Access was granted to all except the submission of the Hungarian government, which only consented to disclosure of its conclusions. Thanks, also, to two anonymous reviewers for their useful comments. The usual disclaimers apply.

${ }^{1}$ ECJ 5 June 2018, Case C-673/16, Coman, Hamilton, Accept v Inspectoratul General pentru Imigrări.

${ }^{2}$ Opinion of AG Wathelet of 11 January 2018 in ECJ Case C-673/16, Coman, Hamilton, Accept v Inspectoratul General pentru Imigrări.

European Constitutional Law Review, 15: 324-339, 2019

(C) 2019 The Authors. This is an Open Access article, distributed under the terms of the Creative Commons Attribution licence (http://creativecommons.org/licenses/by/4.0/), which permits unrestricted re-use, distribution, and reproduction in any medium, provided the original work is properly cited. doi: $10.1017 / S 1574019619000130$ 
Based on the logic that EU citizens might otherwise be dissuaded from using their free-movement rights, EU secondary legislation has long provided them with the right to be joined by family members when moving to another member state. Directive 2004/38 on the free movement of EU citizens ('Citizenship Rights Directive') provides for a derived right of free movement irrespective of the nationality of the family member, hence including third-country nationals. ${ }^{3}$ Family members who must be admitted are defined in Article 2 of the Directive. This includes the spouse, the registered partner (to the extent the home and host member state consider registered partnership the equivalent of marriage), children up until the age of 21 or dependent, and dependent parents. Member states are only under a duty to facilitate the entry and residence of other family members ${ }^{4}$, defined in Article 3(2) as dependents or members of the household of the EU citizen, or with whom the EU citizen is in a durable and duly attested relationship.

Directive 2004/38 applies only to EU citizens who move to or reside in a member state other than their own. However, since an EU citizen might be equally discouraged from exercising his right to free movement if it could not be ensured that upon return he would be able to continue his family life in his home member state, it is established case law that EU citizens returning to their home member states are covered by EU law (Article 21(1) TFEU). ${ }^{5}$ This is only the case if they have genuinely used their free movement rights based on Article 7 of the Directive. $^{6}$ The conditions under which such EU citizens can rely on the right to free movement with respect to their own member states may not be stricter than those laid down by Directive 2004/38, which is to be applied by analogy. ${ }^{7}$

This flows from the fact that, despite the assertion in Article 2 TEU that the Union is based on common values, there are widely diverging views in the various

\footnotetext{
${ }^{3}$ Art. 7(2) of Directive 2004/38/EC of the European Parliament and of the Council of 29 April 2004 on the right of citizens of the Union and their family members to move and reside freely within the territory of the Member States OJ L 158, 30.4.2004, p. 77 (henceforth: the Citizenship Rights Directive).

${ }^{4}$ This requires member states to 'confer a certain advantage, compared with applications for entry and residence of other nationals of third States on applications submitted by persons who have a relationship of particular dependence with a Union citizen', see ECJ 5 September 2012, Case C-83/11, Secretary of State for the Home Department v Muhammad Sazzadur Rahman and Others, para. 21.

${ }^{5}$ ECJ 7 July 1992, Case C-370/90, The Queen v Immigration Appeal Tribunal and Surinder Singh, ex $p$ Secretary of State for Home Department, paras. 21 and 23; ECJ 11 December 2007, Case C-291/05, Minister voor Vreemdelingenzaken en Integratie v R.N.G. Eind, para. 35; ECJ 14 November 2017, Case C-165/16, Toufik Lounes v Secretary of State for the Home Department, para. 52.

${ }^{6} \mathrm{ECJ} 12$ March 2014, C-456/12, O v Minister voor Immigratie, Integratie en Asiel and Minister voor Immigratie, Integratie en Asiel v B, para. 54.

${ }^{7}$ Ibid., para. 50.
} 
member states on the legal recognition of same-sex relations, including opening up civil marriage to same-sex couples. ${ }^{8}$ Whilst there is a marked tendency towards greater recognition, including through marriage, several member states do not provide for any form of legal recognition. Five member states have defined marriage as a union between a man and a woman in their national constitutions. ${ }^{9}$ Romania has included a provision to that effect in its Civil Code. ${ }^{10}$ Although rarely discussed in terms of the culture war, one could consider the topic of marriage equality to be exemplary of deep-running divisions in Europe, both within member states and, importantly, in the EU context, between member states. ${ }^{11}$ The Court has decided the issue primarily on the basis of the free movement of persons. It is argued that although it might be understandable why it did so, the Court, in consequence, has missed an opportunity to send a clear signal that a fundamental rights approach would also require such an outcome.

\section{FACTS OF THE CASE AND PRELIMINARY QUESTIONS}

Mr Coman - a dual US/Romanian citizen - lived and worked in Belgium for a period of close to three years (May 2009-March 2012). In 2010, he married Mr Hamilton, a US citizen and his partner since 2002, who continued to reside in New York. Having failed to obtain legal recognition of their marriage from the Romanian authorities in Brussels, the couple requested the Romanian immigration authorities to grant $\mathrm{Mr}$ Hamilton the right to reside and work legally in Romania as the family member of an EU citizen returning to his home member state. The Romanian immigration authorities refused permission based on Article 277 of the Romanian Civil Code which, in paragraph 2, banned all recognition of civil marriages concluded outside Romania between partners of the same sex. Paragraph 4 of the same article declared the rules on the free movement of EU citizens to be applicable.

Mr Coman and his husband, along with the Romanian LGBTI rights interest group Accept, raised a plea questioning the constitutionality of those provisions of the Civil Code, arguing that they violated their right to personal life, family life and private life and the provisions protecting equal treatment under the Romanian Constitution. The First Instance Court requested that the Romanian

\footnotetext{
${ }^{8}$ Currently, civil marriage has been opened up to same sex couples in 14 member states, as well as in Iceland and Norway (EEA). Registered Partnership is an option in eight other member states, as well as Liechtenstein (EEA) and Switzerland.

${ }^{9}$ Hungary, Latvia, Croatia, Lithuania and Slovakia.

${ }^{10}$ Art. 277(1) of the Romanian Civil Code.

${ }^{11}$ See, however, M. Khan, 'Europe's quiet new culture wars over LGBTI rights', Financial Times, 6 December 2018, 〈www.ft.com/content/d027b3c8-f902-11e8-8b7c-6fa24bd5409c), visited 29 April 2019.
} 
Constitutional Court rule on the plea. The Constitutional Court, in turn, considered that the case raised questions on the interpretation of the Citizenship Rights Directive, in the light of the Charter of Fundamental Rights as well as case law of the Court of Justice of the European Union and the European Court of Human Rights. ${ }^{12}$ It, therefore, referred four questions to the Court in Luxembourg. In essence, it wanted to know whether the term 'spouse' in the Citizenship Rights Directive was to be interpreted to include same-sex spouses and, if so, whether this required a host member state to grant the same-sex spouse rights of entry and residence. In the alternative, the Constitutional Court wished to clarify the extent of member states' obligations under the duty to facilitate the entry and residence under Article 3 of the Directive.

\section{The Court's Ruling}

The Court pointed out that although the Romanian Constitutional Court had only asked about the interpretation of the Citizenship Directive, it was actually more concerned about how Article 21 TFEU should be interpreted, as the Directive itself does not apply to 'returning' EU citizens. This did not prevent the Court from answering the questions, however, as its standing case law allows it to provide the national court with all the elements of interpretation of EU law that are necessary to help it resolve a dispute before it. ${ }^{13}$ Moreover, as the Court had made clear from the outset, its case law on the rights of returning EU citizens and their family members determines that the Directive is to be applied analogously. The Court, proceeding from the referring court's presumption and supported by the Advocate General, determined that Mr Coman had indeed created or strengthened his family life with Mr Hamilton. ${ }^{14}$

As regards the interpretation of the word 'spouse', the Court first referred to its ruling in Metock, holding that the term referred to 'a person joined to another person by the bonds of marriage'. ${ }^{15}$ It argued that, as the term is gender-neutral, it can include a same-sex spouse. ${ }^{16}$ Moreover, as opposed to a registered

\footnotetext{
${ }^{12}$ Request for a preliminary ruling from the Curtea Constituțională a României (Romania) made by decision of 29 November 2016, lodged on 30 December 2016, OJ C 104, 3.4.2017, p. 29.

${ }^{13}$ ECJ 5 June 2018, Case C-673/16, Coman, Hamilton, Accept v Inspectoratul General pentru Imigrări, para. 22.

${ }^{14}$ Ibid., para. 26. See also para. 28 and footnote 11 of the AG's Opinion, distinguishing the facts at hand from ECJ 12 March 2014, C-456/12, O v Minister voor Immigratie, Integratie en Asiel and Minister voor Immigratie, Integratie en Asiel v $B$.

${ }^{15}$ ECJ 5 June 2018, Case C-673/16, Coman, Hamilton, Accept v Inspectoratul General pentru Imigrări, para. 34, with reference to ECJ 25 July 2008, C-127/08, Blaise Baheten Metock and Others v Minister for Justice, Equality and Law Reform, paras 98 and 99.

${ }^{16}$ Coman, Hamilton, Accept v Inspectoratul General pentru Imigrări, ibid, para. 35
} 
partnership, the Directive does not refer to the existence of similar legislation in the host member state. A contrario, a home member state cannot rely on its own national legislation to the extent that it concerns spouses. ${ }^{17}$

The Court was quick to reaffirm that the rules on marriage remained an exclusive competence of the member states and that they were, therefore, free to decide whether to allow marriage between persons of the same sex. ${ }^{18}$ However, the exercise of any competence retained by the member states must be exercised in line with EU law. ${ }^{19}$ Allowing member states to deny recognition to same-sex marriages based on their own legislation would effectively mean that the right of free movement could vary across member states, thereby depriving it of its effectiveness. The Court further pointed out that, in line with its standing case law, the Citizens Directive, which was to be applied analogously, should not be interpreted restrictively. ${ }^{20}$

Having established that non-recognition would amount to a restriction, the Court recalled that such a restriction could only be justified by objective public interest requirements, which would also need to be proportionate (i.e. appropriate and no more restrictive than necessary) to the legitimate objective pursued by the national rule. ${ }^{21}$ The Court then examined the argument that the restriction could be justified on the basis of public policy and the member states' national identity (Article 4(2) TEU). It recalled that its standing case law on the public policy exception required that there be a 'genuine and sufficiently serious threat to a fundamental interest of society'. ${ }^{22}$ It held that recognition for the purpose of granting a derived right of residence to a third-country national did not undermine the institution of marriage, as it did not oblige member states to legislate marriage between partners of the same sex but solely required them to offer recognition for the purpose of enabling the exercise of the right of free movement. ${ }^{23}$ As such, it could not undermine national identity or pose a threat to public policy. ${ }^{24}$

The Court added that any restriction to the right to free movement also needed to comply with fundamental rights protections, as guaranteed by the Charter of Fundamental Rights. ${ }^{25}$ Following the European Court of Human Rights'

\footnotetext{
${ }^{17}$ Ibid., para. 36 .

${ }^{18}$ Ibid., para. 37.

${ }^{19}$ Ibid., para. 38.

${ }^{20}$ Ibid., para. 39.

${ }^{21}$ Ibid., para. 41.

${ }^{22}$ Ibid., para. 44.

${ }^{23}$ Ibid., para. 45.

${ }^{24}$ Ibid., para. 46.

${ }^{25}$ Ibid., para. 47.
} 
interpretation of the European Convention of Human Rights, it confirmed that, under the Charter, same-sex relationships were protected by the right to respect for private life and the right to family life. ${ }^{26}$

These considerations led the Court to reaffirm that a member state could not exclude the same-sex spouse of a returning EU citizen from the concept of 'spouse'. As regards the question of whether this then required the home member state of the returning EU citizen to grant the same-sex spouse a right of residence for more than three months, the Court simply reiterated that the conditions under which a returning EU citizen exercises his right of free movement cannot be stricter than the conditions set by the Citizens Directive. ${ }^{27}$ Article 7 of the Directive, which grants a derived right of residence for periods longer than three months to family members, applies, therefore, by analogy to a same-sex spouse. Having answered the first two questions in the affirmative, the Court no longer needed to examine the questions relating to the position of same-sex spouses under Article 3 of the Directive.

\section{AnALYSIS}

The question put before the Court has been a topic of much academic debate. ${ }^{28}$ It is also one of growing practical relevance due to the diverging recognition accorded to the rights of same-sex partners in Europe and the increased protection given to same-sex couples by the European Court of Human Rights. ${ }^{29}$ Cases on the rights of same-sex partners have tended to reach the European Court of Justice

\footnotetext{
${ }^{26}$ Ibid., para. 49, making reference to Art. 52(3) of The Charter of Fundamental Rights of the European Union (henceforth: the Charter).

${ }^{27}$ Ibid., para. 54.

${ }^{28}$ See e.g. M. Bell, 'Holding back the tide? Cross-border recognition of same-sex partnerships within the European Union', 12 Eur Rev Priv Law (2004) p. 613; D. Kochenov, 'On options of citizens and moral choices of states: gays and European federalism', 33 Fordham Int Law J (2009) p. 156; H. Toner, 'Migration rights and same-sex couples in EU law: a case study', in K. Boele-Woelki and A. Fuchs (eds.), Legal Recognition of Partnerships in Europe (Intersentia 2012) p. 285; J.J. Rijpma and N.R. Koffeman, 'Free Movement Rights for Same-Sex Couples under EU law: What Role to Play for the European Court of Justice?', in D. Gallo et al. (eds.), Same Sex Couples Before National, Supranational and International Jurisdictions (Springer Verlag 2014) p. 455; A. Tryfonidou. 'EU free movement law and the legal recognition of same-sex relationships: the case for mutual recognition', 21 Columbia J of Eur Law (2015) p. 195.

${ }^{29}$ Starting with the landmark case of ECtHR 24 June 2010, Case No. 30141/04, Schalk and $K o p f \mathrm{v}$ Austria, which brought same-relationships within the scope of family life, para. 94.
} 
mostly as staff cases or preliminary references in the field of equal treatment in employment and occupation. ${ }^{30}$ The reason it has taken so long for this specific question on free-movement rights to reach Luxembourg may well lie in the fact that in a same-sex couple consisting of two member state nationals, each spouse is able to independently claim rights of free movement as an EU citizen. This is different, however, for third-country-national family members; they can only invoke derived rights based on their link to the EU citizen. Lastly, it took a brave individual, Adrian Coman, to come forward, not shying from the spotlight and even refusing to have the name of the case anonymised. He did so with the support of the Romanian LBGT interest group Accept, which had already successfully brought a case fighting LGBT discrimination before the European Court of Justice. ${ }^{31}$ The Coman case is, therefore, also a fine example of successful strategic litigation.

\section{The definition of spouse and the existence of a restriction}

The Court clearly acknowledged the sensitivities this case posed for certain member states. It situated the dispute squarely within the framework of the internal market freedoms, i.e. the right to free movement, rather than framing it as a fundamental rights issue. In fact, it only mentioned fundamental rights as a final and supporting argument. It is not uncommon for the Court to do so; many of its judgments that have been applauded for protecting the right to family life, such as the Carpenter and Baumbast cases, have been decided on an economic rationale, namely preventing restrictions to the EU citizen's right to free movement rather than the fundamental rights of that citizen or his family members. ${ }^{32}$

The member states that intervened on the side of the Romanian government Poland, Hungary, and Estonia - each referred to the legal basis for rules on family law having cross-border implications in Article 81(3) of the TFEU, and the fact

\footnotetext{
${ }^{30}$ See, for instance, staff cases: ECJ 31 May 2001, Joined Cases C-122/99 P \& C-125/99 P, D and Sweden v Council; GC 5 October 2009, T-58/08 P, Commission of the European Communities v Anton Pieter Roodhuijzen. See in the field of employment: ECJ 17 February 1998, C-249/96, Lisa Jacqueline Grant v South-West Trains Ltd.; ECJ, 1 April 2008, C-267/06, Tadao Maruko v Versorgungsanstalt der deutschen Bühnen; ECJ 10 May 2011, C-147/08, Jürgen Römer v Freie und Hansestadt Hamburg, ECJ 12 December 2013, C-267/12, Frédéric Hay v Crédit agricole mutuel de Charente-Maritime et des Deux-Sèvres; ECJ 24 November 2016, Case C-443/15, David L. Parris v Trinity College Dublin and Others.

${ }^{31}$ ECJ 25 April 2013, Case C-81/12, Asociația Accept v Consiliul Național pentru Combaterea Discriminării.

${ }^{32}$ ECJ 11 July 2002, Case C-60/00, Mary Carpenter v Secretary of State for the Home Department, para. 39; ECJ 17 September 2002, Case C-413/99, Baumbast and Rv Secretary of State for the Home Department, para. 73.
} 
that this article has so far gone unused and requires unanimity. Not surprisingly, the Court, as had the Advocate General, discarded these arguments. Whilst reaffirming that member states were free to legislate or not legislate marriage for persons of the same sex, the Court recalled its long-standing case law by which member states, even in areas of exclusive competence, were bound by EU law in the exercise thereof, as mandated by the principle of primacy and loyal cooperation. ${ }^{33}$ In this regard, it should also be noted that Article 81(3) TFEU is situated in the title on the Area of Freedom, Security and Justice and does not apply to all member states. ${ }^{34}$ As such, it would have been problematic to allow that article to guide the interpretation of internal market provisions, which are applicable to all member states.

The Court, in defining the term spouse, hardly referred to its prior case law on same-sex relationships, in which it had explicitly referred to marriage as a union between a man and a woman. ${ }^{35}$ However, in all these cases, the question was whether a non-marital same-sex relationship could be equated with a long term same-sex relationship, admittedly in instances in which civil marriage was not available to same-sex partners. It seems that this case law remains valid, even more so now that civil marriage is now an option open to same-sex couples in a growing number of member states. However, the absence of any explicit reference to this case law is interesting because, when the Court referred in those cases to the need to respect EU law in the exercise of exclusive competence, it also referred specifically to the principle of non-discrimination. ${ }^{36}$

The Court, unlike the Advocate General, did not pay much attention to the legislative history of the provision in question. ${ }^{37}$ It is nonetheless interesting to recall that an explicit reference to same-sex spouses, as proposed by the Parliament, was not accepted by the Council at the time, despite the fact that two member states - Belgium and the Netherlands - had already opened up civil marriage to same-sex couples by then. The Commission, in its amended proposal of the Directive, had indicated that it would leave the definition of spouse deliberately open-ended to allow for 'a possible change

\footnotetext{
${ }^{33}$ ECJ 5 June 2018, Case C-673/16, Coman, Hamilton, Accept v Inspectoratul General pentru Imigrări, paras 37-38, referring to ECJ 24 November 2016, Case C-443/15, David L Parris v Trinity College Dublin and Others, para. 59.

${ }^{34}$ Protocol (No 21) on the Position of the United Kingdom and Ireland in respect of the Area of Freedom, Security and Justice and Protocol (No 22) on the position of Denmark.

${ }^{35}$ See the case law referred to supra note 30, more specifically D and Sweden v Council, para. 34.

${ }^{36}$ ECJ 24 November 2016, Case C-443/15, David L. Parris v Trinity College Dublin and Others,

${ }^{37}$ See the AG's Opinion, para. 51.
} para. 58. 
in interpretation in the light of developments in family law in the member states'. ${ }^{38}$ In its written intervention, the Commission explicitly reconsidered its position in light of societal and jurisprudential developments since the adoption of the Directive, confirming a position that it had already implicitly put forward in its interpretative guidelines to the Directive, arguing that validly contracted marriages in one member state would need to be recognised in another. ${ }^{39}$

Whereas the Advocate General argued that the term 'spouse' should be interpreted as an autonomous concept of EU law, his approach and that of the Court are much more informed by the logic of mutual recognition. Although the Court refers to its definition of spouse as 'a person bound by the ties of marriage', marriage is, in turn, defined by making reference to the home member state's legislation. ${ }^{40}$ Admittedly, it would have been hard to provide a definition of marriage that did not refer to some form of formalisation in national legislation. Some commentators have also noted that whereas the Advocate General had referred to marriages no matter where they had been concluded, the Court only spoke of marriages concluded in another member state. ${ }^{41}$ It is submitted that this should prevent a member state from refusing to recognise a same-sex marriage concluded outside the EU for the purpose of applying the rules of free movement if: (a) its own rules of private international law recognise non-EU marriages concluded between individuals who are not of the same sex; or (b) the home member state has already recognised the marriage under its own rules of private international law.

Unlike the Court, the Advocate General did examine the questions regarding the rights of same-sex partners under Article 3(2) of the Citizenship Rights Directive. This provision has, in practice, served as a much used 'fall back option' in member states that fail to recognise foreign marriages between same-sex partners. In his view, the marriage of an EU citizen with a same-sex spouse would have to be considered to be indicative of a durable and stable relationship, a view also expressed in the written submissions of the Polish government. ${ }^{42}$ However,

${ }^{38} \mathrm{COM}(2003) 199$ final, p. 11.

${ }^{39} \mathrm{COM}(2009) 313$ final, p. 4.

${ }^{40}$ ECJ 5 June 2018, Case C-673/16, Coman, Hamilton, Accept v Inspectoratul General pentru Imigrări, para. 34 .

${ }^{41}$ S. Peers, 'Love wins in the CJEU: Same Sex Marriages and EU free movement law', EU Law Analysis, 5 June 2018, 〈www.eulawanalysis.blogspot.com/2018/06/love-wins-in-cjeu-same-sexmarriages.html $\rangle$, visited 29 April 2019, and A. Tryfonidou, 'Free Movement of Same-Sex Spouses within the EU: The ECJ's Coman judgment', European Law Blog, 19 June 2018, 〈www.europeanlawblog.eu/tag/coman-case/〉, visited 29 April 2019.

${ }^{42}$ AG Opinion, para. 93. The Hungarian government concluded that a same-sex spouse could, in principle, be included under Art. 3(2) of the Directive but that this depended on the circumstances of the individual case. 
it must be stressed that even when applied without discrimination, this article could not form a valid alternative for an inclusive reading of the term 'spouse', as it only requires a member state to facilitate entry and residence and can therefore not guarantee the full effectiveness of EU free movement rights. It would also create uncertainty about the position of same-sex spouses and other family members once they have been admitted, in particular as regards the equal treatment under Article 24 of the Directive. ${ }^{43}$

A broader critique could be launched against the Court and the way in which EU law deals with non-marital relationships. If, indeed, as the Advocate General remarked in his Opinion, 'EU law must be interpreted 'in the light of present day circumstances', that is to say, taking the 'modern reality' of the Union into account ${ }^{4}{ }^{44}$ the question of whether EU law, its provisions relating to registered partnerships and durable non-registered/non-marital relationships, in particular, does justice to a societal reality in which people increasingly choose to conduct their relationships outside the bonds of marriage. ${ }^{45}$ As such, marriage - if and where available - is rendered a conditio sine qua non for the exercise of free movement rights - for same-sex and opposite-sex couples alike. The Advocate General did, however, show some understanding of modern day relationships, concluding that 'in a globalised world' not living together at all times does not necessarily affect the existence of a stable relationship. ${ }^{46}$

\section{The existence of a justification}

It is clear that the non-recognition of a same-sex spouse would amount to a restriction of the free movement, easily crossing the threshold of 'a 'serious

\footnotetext{
${ }^{43}$ ECJ 25 February 2016, Case C-299/14, Vestische Arbeit Jobcenter Kreis Recklinghausen v Jovanna Garcia-Nieto and Others. Although, admittedly, this case was decided in relation to EU citizens residing in the host member state on the basis of Art. 6 of the Directive, it could be argued that they should have qualified for equal treatment as family members within the definition of Art. 3(2) of the Directive.

${ }^{44}$ AG Opinion, para. 56.

${ }^{45} \mathrm{~A}$ different but similar reference related to non-traditional (western) family forms is currently pending before the Court, which seeks to ascertain whether a child under permanent legal guardianship known as 'kefalah', a concept of Islamic law similar to adoption, must be considered a direct descendant in the sense of Art. 2(2)(c) of the Directive (Case C-129/18, SM, Request for a preliminary ruling from the Supreme Court of the United Kingdom made on 19 February 2018, OJ C 134, 16.4.2018, p. 17).

${ }^{46} \mathrm{AG}$ Opinion, para. 28.
} 
inconvenience' at administrative, professional and private levels, ${ }^{47}$ The Court made it clear that such a restriction could not be justified by a legitimate interest requirement. It is submitted that the Court was correct in doing so, but that this was not self-evident.

In a 2011 article, Lenaerts, writing in an extra-judicial capacity, had argued that excluding a same-sex spouse from the scope of the word spouse would indeed constitute a restriction to free movement but that the Court should determine whether such a restriction could be justified on a case-by-case basis. ${ }^{48}$ However, that approach might have resulted in significant legal uncertainty for same-sex couples and their free movement rights being interpreted differently across the EU. The Court was, therefore, right not to follow this approach. Also, the Advocate General had emphasised the importance of legal certainty for the interpretation of the Directive. ${ }^{49}$

The Court did not explicitly state that the protection of family life could be a legitimate interest worthy of protection, nor did it concede that protection of family life or barring same-sex partners from civil marriage might constitute part of a member state's national identity - a point that, interestingly enough, was raised by only one member state, Latvia, and only during the oral proceedings. Instead, it argued that recognition of same-sex marriage would not affect the meaning of marriage in the member state itself. ${ }^{50}$ Thus, rather than recognise the existence of a legitimate interest followed by an examination of the proportionality of the national measure invoked to protect it, the Court argued that the legitimate interest invoked had never actually been affected, to begin with.

It is doubtful whether, in light of the Coman-case, the rules of the Citizenship Rights Directive that apply to registered partners can still be considered to be in compliance with primary EU law, in particular in situations in which the host member state does not provide for any form of legal recognition of same-sex partners. Such a lack of recognition might on its own constitute a violation of the European Convention on Human Rights, considering that the European Court of Human Rights has already been willing to find a violation of Article 8 of the Convention in the absence of any form of legal recognition of

${ }^{47}$ ECJ 12 May 2011, C-391/09, Malgožata Runevič-Vardyn and Eukasz Paweł Wardyn v Vilniaus miesto savivaldybes administracija and Others, para. 76 and the case law cited therein.

${ }^{48} \mathrm{~K}$. Lenaerts, 'Federalism and the rule of law: perspectives from the European Court of Justice', 33 Fordham Int Law J (2011) p. 1338 at p. 1360-1361. Note that in a later (co-authored) article, he is less outspoken, stating that it would be interesting to see how the Court might interpret the concept of 'spouse': K. Lenaerts and J.A. Gutierrez-Fons, 'To Say What the Law of the EU Is: Methods of Interpretation and the European Court of Justice', 20 Colum J Eur L (2013-2014) p. 3 at p. 49.

${ }^{49} \mathrm{AG}$ Opinion, para. 76.

${ }^{50}$ ECJ 5 June 2018, Case C-673/16, Coman, Hamilton, Accept v Inspectoratul General pentru Imigrări, para. 45. 
same-sex partners. ${ }^{51}$ At the same time, it could be argued that judgment should be read in the specific national context of the case, one in which the national legislature had failed to answer calls by the highest judicial authorities for the recognition and protection of same-sex relationships. ${ }^{52}$

The Court did not engage with the argument made most forcefully by the Polish Government in its written observations, i.e. that recognition of the same-sex partner for purposes of entry and residence could have unforeseen consequences for the host member state. The argument that equal treatment of samesex spouses could have implications for matters beyond mere entry and residence would seem to be correct. There appears to be no valid reason to assume that Article 24 of the Directive, which establishes the right of EU citizens and their family members to be treated equally to nationals of the host member state, should not apply - by analogy - to same-sex spouses, since that article also governs the conditions under which EU citizens may exercise their free movement rights. It would, however, be difficult to understand why this could have led the Court to reach any different conclusion. Not only would any limitation on the equal treatment of family members compared to nationals of the host member state constitute discrimination on grounds of nationality, the same could be said of discrimination on grounds of sexual orientation; recital 31 of the Directive underscores that member states must apply the Directive in line with the Charter and the prohibition of discrimination contained in Article 21.

The Court's rejection of the public order exception can be contrasted with its rulings in Sayn Wittgenstein and Runevič-Vardyn. ${ }^{53}$ In those cases, national constitutional identity, either on its own or in combination with public policy, played out in favour of the member states invoking them, thus allowing those member states to maintain national rules with regard to family names despite the fact that the Court had not explicitly recognised that family names form part of an individual's private life. ${ }^{54}$

Still, the way the Court chose to apply the concept of constitutional identity, namely by linking it firmly to previously accepted derogations, in this case public

${ }^{51}$ ECtHR 21 July 2015, Case Nos. 18766/11 and 36030/11, Oliari and Others v Italy, para. 185, as also noted by the AG in footnotes 25 and 42 to his Opinion. Note, also, that the Staff Tribunal has been willing to take into consideration whether access to marriage is practical and effective, 14 October 2010, Case F-86/09, W v Commission, para. 44.

${ }^{52}$ Oliari and Others v Italy, ibid, para. 180.

${ }^{53}$ ECJ 22 December 2010, Case C-208/09, Ilonka Sayn-Wittgenstein v Landeshauptmann von Wien, and ECJ 12 May 2011, Case C-391/09, Malgožata Runevič-Vardyn and Łukasz Pawet Wardyn $\mathrm{v}$ Vilniaus miesto savivaldybes administracija and Others.

${ }^{54}$ Ilonka Sayn-Wittgenstein v Landeshauptmann von Wien, ibid, para. 66 and Malgožata RunevičVardyn and Łukasz Pawet Wardyn v Vilniaus miesto savivaldybes administracija and Others, ibid, para. 52. 
policy, is quite similar. ${ }^{55}$ The reluctance of the Court to fully engage with the concept of constitutional identity can also be observed in the $M A S$ and $M B$ case, in which it cast its answer in terms of the common constitutional traditions of the member states rather than as part of constitutional identity, despite the Italian Constitutional Court's explicit reference to the concept. ${ }^{56}$ The Court might have recognised the right of member states to exclude people of the same sex from entering into civil marriage as constituting part of their constitutional identity while still ruling that this could not trump the primacy of free movement rules or outweigh the fundamental rights and freedoms of EU citizens. ${ }^{57}$ This would have had the advantage of once again acknowledging the sensitivities with regard to marriage equality in certain member states, whilst making it clear that these cannot prevent married couples of the same sex from exercising their free movement rights.

At this point, it should be noted that the government of the Netherlands, the first member state to open up civil marriage to same-sex couples, was the only member state to intervene, along with the European Commission, on the side of $\mathrm{Mr}$ Coman. It should be commended for doing so, for if marriage equality is to be considered close to the heart of progressive liberal democracies, the latter should take any opportunity that presents itself to defend the values they stand for, much as the other intervening member states were willing to advocate their stance on the issue.

\section{Compliance with fundamental rights}

The Court may have been wise to frame the issue at stake as a question of internal market law rather than one of fundamental rights, thus allaying some of the concerns of the member states that vehemently opposed same-sex marriage. At the same time, the Court's most cursory reference to fundamental rights and the case law of the European Court of Human Rights could be criticised as overly cautious. An additional line of argumentation grounded in fundamental rights might have reinforced the outcome of the case. Instead, the Court merely recalled that any restriction of a fundamental freedom must be in line with the provisions of the

${ }^{55} \mathrm{~J}$. Sterck, 'Sameness and selfhood: The efficiency of constitutional identities in EU law', 24 ELJ (2018) p. 281 at p. 289.

${ }^{56}$ ECJ 5 December 2017, Case C-42/17, Criminal proceedings against M.A.S. and M.B. See G. Piccirilli, 'The "Taricco Saga": the Italian Constitutional Court continues its European journey', 14(4) EuConst (2018) p. 820. This is similar to the approach that was adopted in ECJ 14 October 2004, C-36/02, Omega Spielhallen- und Automatenaufstellungs-GmbH v Oberbürgermeisterin der Bundesstadt Bonn, para. 34.

${ }^{57}$ M. van den Brink, 'Is the Reasoning in "Coman” as Good as the Result?', 10 June 2018, 〈www.verfassungsblog.de/is-the-reasoning-in-coman-as-good-as-the-result/〉, visited 29 April 2019. 
Charter, interpreted in line with the European Convention of Human Rights. ${ }^{58}$ It then proceeded to dedicate a mere paragraph to the Strasbourg case law according to which same-sex relationships fall within the notion of private life and family life. $^{59}$

The Court of Justice failed to explicitly state that the case law of the European Court of Human Rights itself required that the notion of 'spouse' be broadly interpreted to include same-sex spouses. It referred to Orlandi and Other v Italy, in which the Strasbourg Court had found a violation of the right to private and family life for refusing to register foreign marriages between same-sex partners in the absence of any form of legal recognition, but did not draw any explicit conclusion from that case. ${ }^{60}$ Even assuming that that ruling needs to be read in the particular national context of the case, the Court of Justice could have chosen to interpret the Charter as offering more protection than the Convention. ${ }^{61}$ Even though marriage equality is not universally supported, attitudes toward it in the European Union as a whole are much more favourable than within the much broader Council of Europe; this warrants a more progressive interpretation of the Charter than of the Convention.

The Court of Justice also failed to explicitly state that the European Court of Human Rights had previously held that a distinction based on sexual orientation could only be made based on 'particularly serious reasons'. ${ }^{62}$ In a case involving a refusal to grant family reunification -marriage was not an option available to the partners involved - the Court held that whilst protection of the traditional family unit might constitute a legitimate aim, it was not a 'particularly convincing and weighty' reason capable of justifying discrimination on grounds of sexual orientation under those circumstances. ${ }^{63}$

It is perhaps understandable that the European Court of Justice chose not to examine the right to marry and found a family, as recognised by Article 9 of the Charter. Not only was this not required to answer the case, but the European Court of Human Rights has also, to this day, maintained that the right to marry does not extend to same-sex spouses. ${ }^{64}$ However, it is regrettable that the Court let pass an opportunity to engage with the right to human dignity. This right

\footnotetext{
${ }^{58}$ ECJ 5 June 2018, Case C-673/16, Coman, Hamilton, Accept v Inspectoratul General pentru Imigrări, para. 49, referring to Art. 52(3) of the Charter.

${ }^{59}$ Ibid., para. 50.

${ }^{60}$ ECtHR 14 December 2017, Case Nos 26431/12; 26742/12; 44057/12 and 60088/12, Orlandi and Others v Italy, para. 209.

${ }^{61} \mathrm{Art} .52(3)$ of the Charter.

${ }^{62}$ ECtHR 30 June 2016, Case No 51362/09, Taddeucci and McCall v Italy, para. 89.

${ }^{63}$ Ibid., para. 93.

${ }^{64}$ ECtHR 21 July 2015, Case Nos. 18766/11 and 36030/11, Oliari and Others v Italy, para. 192.
} 
underpins all the rights protected by the European Convention on Human Rights and is laid down explicitly in Article 1 of the Charter. ${ }^{65}$ It is this right that has played a key role in many national constitutional court cases on the right of samesex partners to marry. ${ }^{66}$ Arguably, the ruling in Orlandi and Other v Italy can be read in that light. The European Court of Justice could easily have made the case that stripping someone of his marital status upon exercising his free movement rights was an affront to human dignity. ${ }^{67}$

\section{CONCLUDing REMARKS}

The EU is not a human rights organisation and its Court of Justice, despite protecting fundamental rights within the EU legal order, is not a human-rights tribunal. Nor is the EU a federal state and its Court, despite fulfilling many similar functions, is not a Constitutional Court. In consequence, the Coman case is not, and could never have been, Europe's Obergefell, the US Supreme Court case that opened up civil marriage to same-sex partners in all US states. ${ }^{68}$ The European Court of Justice should be applauded for the consistent and non-discriminatory application to all EU citizens, irrespective of sexual orientation, of its own case law on the fundamental freedom of movement. This has allowed the Court to arrive at an answer that is satisfactory from a fundamental rights perspective without taking a more controversial fundamental rights approach. At the same time, fundamental rights are an integral part of the EU legal order. The Court might have strengthened its argument whilst remaining within the boundaries of its jurisdiction, stating more explicitly that respect for fundamental rights would not have yielded any other outcome.

The advocates and opponents of marriage equality can be expected to continue to cross swords in future. Although real change could, in theory, come from Strasbourg, it would seem that, for now, the European Court of Human Rights is only willing to go as far as to require, short of marriage, some form of legal recognition. Activist lawyers might elect to continue bringing actions before national constitutional Courts, although with uncertain results. Whilst

${ }^{65}$ ECtHR 24 April 2002, Pretty v the United Kingdom, Case No 2346/02, para. 65.

${ }^{66}$ See e.g. Court of Appeal for Ontario, Halpern v Attorney General (2003) 65 OR (3d) 161, para. 5; Constitutional Court of South Africa, Minister of Home Affairs and Another v Fourie and Another; Lesbian and Gay Equality Project and Others v Minister of Home Affairs and Others [2005] ZACC 19, para. 78 per Sachs J.

${ }^{67} C f$ Ninth District Court of Appeals of California 7 February 2012, Perry v Brown, Nos. 10-16696, 11-16577, per Judge Reinhardt, p. 5.

${ }^{68}$ United States Supreme Court 26 June 2015, Case No 14-556, Obergefell et al. v Hodges, Director, Ohio Department of Health et al. See also M. Finck, 'The role of human dignity in gay rights adjudication and legislation: A comparative perspective', 14 I-Con (2016) p. 26. 
the Romanian Constitutional Court did rule in the Coman case in compliance with the answers to its preliminary questions, it nonetheless failed to seize the opportunity to address the issue of marriage equality on the basis of the rights protected in its own constitutional order. ${ }^{69}$ As such, the recognition of a marriage between persons of the same sex remains yet another imposition by 'Europe'.70

${ }^{69}$ Romanian Constitutional Court Decision No. 534, 18 July 2018, 〈www.ccr.ro/files/products/ decizia_534_2018.pdf), visited 29 April 2019. See, however, Austria: VfGH 4.12.2017, G 258/ 2017.

${ }^{70}$ E. Brodeala, 'Paying Lip Service to the CJEU: The Unsurprising Decision of the Constitutional Court of Romania in the Coman Case', EUI Blogs, 29 July 2018, 〈blogs.eui.eu/constitutionalismpolitics-working-group/paying-lip-service-cjeu-unsurprising-decision-constitutional-court-romaniacoman-case/ $\rangle$, visited 24 May 2019. 